\title{
Bogkataloget
}

\section{Indledning: Det tekstuelle sønderfald}

Det skal ikke være nogen hemmelighed, at denne tekst har voldt mig gevaldige problemer. Ikke fordi jeg tror, det har med denne tekst eller dens emne at gøre, men fordi det at skrive tekster generelt igennem længere tid har givet mig problemer af nærmest etisk kaliber. Her vil jeg nødig misforståes: jeg har siden puberteten været skribent, og skriverier hører til min daglige dont. Ganske uproblematisk. Men i den sidste tid har jeg foretrukket tekster uden kausalitet, uden begyndelse, uden slutning, uden sætninger (jeg foretrækker termen 'tekststrenge') og helst uden holdninger; og hvor meningen, eller betydningen, ligger i - den betingede og variable - sammenkædning af disse strenge. Det drejer sig typisk om katalogposter og lister, biografiske trivia, historiske anekdoter og værdiløse kendsgerninger eller kuriøse sammenfald, alt sammen uendeligt kombinerbart med enhver anden tekststreng. Jeg tror ikke, sygdommen er ukendt. Jeg indbilder mig i det mindste selv at kunne iagttage den i store dele af den skønlitterære produktion i dag.

Men denne tekstproduktion er i grunden en anden historie. Jeg nævner det dog allerede her som indledning, fordi grunden til dette skift i skrift i høj grad har med mit emne at gøre (det er for så vidt almengyldigt). Jeg kan ikke sige, hvornår denne erosion af tekstuel mening for mit vedkommende begyndte, men et afgørende punkt var, da jeg den 18. maj 2002, uden fast bopæl, og mod bedre vidende, spenderede en - efter omstændighederne - katastrofalt stor sum (600 DKK) af mine få likvide midler på en bog, som jeg dagen inden havde fået øje på i Arnold Buscks antikvariat, og som jeg hele natten lå og skiftevis drømte om og vågnede og længtes efter, inden jeg om formiddagen efter tilpas passende påklædning og tandbørstning tømte min tegnebog hos hin velkendte antikvarboglade. Bogen, som i den grad optog mig, var:

Bibliotheca Magica et Pneumatica. Geheime Wissenschaften. Sciences occultes. Occult sciences. Folklore. Kataloge 31-35. Jacques Rosenthal, München. 10 KarlStrasse 10. U.å. [c.1907]. In-8. 48 pp. [Register], 680, [1], [blank] pp. Kunstldrbd. 
ALCHEMY, MAGIC ART, CURIOSITIES,

UTOPIAS, NATURAL SCIENCES, MINING,

ARCHITECTURE, MECHANICS AND THEIR

BIBLIOGRAPHY AND LITERARY HISTORY
Omslaget til Catalogue of Old and Rare Books ... Lantos \& Co. 1923

ON SALE BY

THE LANTOS Co. LTD.

BUDAPEST, NV. MUZEUM-KÖRƯT 3

PRICES IN SWISS FRANCS

Købet var - kræmmermæssigt - godt, ser jeg nu efterfølgende, men det vigtige var, at denne bog blev min eneste kilde til litteratur de følgende mange måneder. Vigtigere endda var dog, at det gik op for mig, at kataloget slet ikke var en "kilde" til litteratur: det var selv litteratur.

Bibliotheca Magica et Pneumatica har jeg siden maj 2002 skrevet løbende af, som Louis Jacob de Saint-Charles i sin Bibliographia Parisiana (1645-1651) definerer bibliografi: "skrivning og afskrivning af bøger". I skrivende stund er jeg blot nået til post no. 2129 af 8875, men man kan roligt slå op hvor som helst og finde den mest herlige lapidariske form for litteratur (med værdiangivelser!). I løbet af disse måneder med Bibliotheca Magica et Pneumatica som eneste selskab gik det op for mig, at af de bøger, som var mig mest kære, var en forbavsende stor del kataloger og bibliografier; jeg tænkte på alle Björck \& Börjesons kataloger (et svensk antikvariat, jeg aldrig fik oplevet), på Jahrbuch der Auktionspreise, på Catalogues raisonnées over kunstnere, Museums-inventarier, håndskriftskataloger, på alle antikvarkataloger som jeg har tigget mig til hos antikvarhandlerne, på Eduard Grisebachs Weltlitteratur-Katalog. Mit literarischen und bibliographischen Anmerkungen (Berlin 1913) og så fremdeles i det uendelige, men frem for alt tænkte jeg på:

Catalogue of Old and Rare Books in Alchemy, Magic Art, Curiosities, Utopias, Natural Sciences, Mining, Architecture, Mechanics and Their Bibliography and Literary History. On Sale by The Lantos Co. Ltd. Budapest, IV. Muzeum-Körut 3. No. 29 1923. In-4, 76 pp. +4 pp Index, i privat halvlærredsbind.

som jeg fik fat på i et antikvariat i Budapest (Központi Antikv., Múzeum krt.) den 28. februar 1996 for en slik (500 HFl., svarende til 23 kroner). I en vis forstand er dette salgskatalog bibliografiens svar på Jacob Jordaens i sin alkoholiserede yppighed: med interfolierede blanke blade, med en særdeles skøn og stor typografi, og med sin sløsede omgang med sideplads. Det er ikke mange poster, som får plads i det, men posterne er udsøgte. Kataloget er ikke bare en sjældenhed i sig selv, men eksemplaret, som jeg fik fat i, er også herligt på en anden måde, derved at de interfolierede blanke sider faktisk er blevet brugt til håndskrevne noter af en ved auktionen tilstedeværende bibliofil, som dog intet skrev om teksterne, men blot kommenterede de handlede objekters værdi. 
Også dette sidstnævnte forhold - at den handlende blot kommenterer priser og ikke tekster - vil jeg senere komme ind på, men hovedpointen i det følgende vil være, at disse indledende betragtninger peger på en problematik af større almen-litterær relevans, som vi i de senere årtier også har kunnet iagttage i skønlitteraturens (og kunstens) omgang med sit "stof".

\section{I: Det konceptuelle værk}

Fra min kunstinteresserede ungdom er i særdeleshed ét værk forblevet hængende i min bevidsthed på den der særligt irriterende og insisterende måde, hvormed visse værker bliver ved med at gøre sig gældende. I kender det sikkert godt. Dette bevidsthedsmæssige vedhæng er desto mere irriterende, eftersom jeg ikke synes værket er specielt godt, dets pointe er ovenikøbet temmelig klar og én-dimensionel, og værket skiller sig overhovedet ikke ud fra tidens værker i øvrigt. Det irriterende værk, jeg tænker på, er Lawrence Weiners A Square Removal From A Rug In Use fra 1969. Jeg så først værket reproduceret i en lille tynd essaysamling af den svenske kunstkritiker Mats B. (För en idébaserad konst. Cavefors 1975) og har hverken set eller hørt om det siden. Til alle af Lawrence Weiners værker (i det mindste fra denne tid) hørte en slags 'brugsanvisning' eller statement, som man siger på kunstnerisk. Denne brugsanvisning var, sammen med titlen, formuleret som en slags algoritme bestående af tre kendte størrelser (kunstneren, modtageren og stykket), mellem hvilke tilsyneladende uendeligt store frihedsgrader kunne virke:

1. The artist may construct the piece. 2. The piece may be fabricated. 3 . The piece need not be built. Each being equal and consistent with the intent of the artist; the decision as to condition rests with the receiver upon the occasion of receivership.

Sommetider har jeg fået lyst til at fremstille værket (i overensstemmelse med mulighed nr. 2), blot for dagen efter at indse, at det er slet ikke er værkets materialitet, som interesserer mig. Men da jeg - som så mange andre - også lider af "collectitis", irriterer det mig en kende, at jeg slet ikke har 'modtaget' værket. Eller rettere sagt: jeg kan ikke få 'modtagelsen' eller receptionen af værket til at passe ind i muligheden for at eje det. Det er denne diskrepans mellem værkets reception som en ideel og konceptuel reception på den ene side og muligheden af at eje eller beskrive værkets fysiske væren på den anden side, som er blevet ved med at irritere mig.

Jeg har en mistanke om, at den amerikanske maler Douglas Gorsline oplevede en tilsvarende irritation, da han i 1964 spurgte Duchamp, om han mon ikke ville signere et nyligt indkøbt flasketørrestativ. Til Gorslines forespørgsel svarede Duchamp blot: "I Milano har jeg netop indgået en aftale med Schwarz, som autoriserer ham til at producere en edition (8 replikaer) af alle mine få readymades, inklusive flasketørrestativet. Jeg har derfor pålagt mig selv ikke længere at signere readymades for at beskytte denne edition. Men signeret eller usigneret, dit fund har samme 'metafysiske' værdi som en hvilken som helst anden readymade. Det har desuden den fordel at det fuldstændig savner kommerciel værdi." 
Elfriede Jelinek er - og deri ligner hun såvel mig som Douglas Gorsline - ikke ligeglad med penge, men alt taler ikke desto mindre for, at det er denne fuldstændige foragt for kommerciel værdi, som har fået hende til at publicere sin nyeste roman, Neid. Privatroman, på nettet, og kun på nettet, for på den måde at fjerne sig fra forlagssystemets kommercielle side, men måske først og fremmest for at fjerne sig fra samlernes interne begærssystem drevet af netop griskhed (avaritia) og misundelse (invidia) med meget få frihedsgrader. Ligesom Lawrence Weiner og Marcel Duchamp laver værker, som ikke vil være kunst, skriver Elfriede Jelinek tekster, som ikke vil være bøger: 1 . Forfatteren kan trykke teksten. 2. Teksten kan trykkes. 3. Teksten behøver ikke trykkes. Hver mulighed er ligeværdig og konsistent med forfatterens intention; afgørelsen med hensyn til værkets tilstand er hos modtageren i modtagelsestilfældet.

Fælles for Weiner, Duchamp og Jelinek er, at de stræber efter at erstatte den 'traditionelle' formel for kunstnerisk intention, kausalitet og reception, som går fra forfatteren (kunstneren) over værket til læseren (recipienten):

$$
\text { FORFATTER } \rightarrow \text { VÆRK } \rightarrow \text { LÆSER }
$$

og som implicerer, at en forfatter skriver et til flere værker, som efterfølgende når ud til en eller flere læsere - til en mere umiddelbar form for kommunikation uden for kunst- eller forlagssystemets kommercielle forvrængninger:

FORFATTER $\rightarrow($ VÆRK $) \rightarrow$ LÆSER

eller for at betone, at læseren i større eller mindre grad selv er ansvarlig for værkets realisering:

FORFATTER $\rightarrow$ VÆRK $\leftarrow$ LÆSER

som det bl.a. formuleres i Marcel Duchamps foredrag "The Creative Act" fra 50erne, hvor det bliver eksemplarisk tydeligt, at værket, ved kunstnerens uudtrykte hensigt (unexpressed intention), først bliver virkeliggjort ved beskuerens uhensigtsmæssige udtryk (the unintentionally expressed).

\section{II: Den inverterede forfatter}

“Jeg er antikvarboghandler. Jeg læser ikke bøger," er det svar, som jeg indbilder mig at have hørt en svensk antikvarboghandler give - med en stille, men eftertrykkelig stemme og uden at løfte blikket fra det, som for øjeblikket optog ham - en kunde, som spurgte til en bogs handling.

Det er nu meget lang tid siden, men jeg er ret sikker på, at det var i Malmö. Jeg vil gerne tro, at det var Persson den ældre på Perssons Antikvariat (Amiralsgatan 8), som sagde det, men når jeg tænker godt efter, tror jeg nok snarere, at det drejede sig om Greger på Gregers Antikvariat (Helmfeltsgatan 5). Jeg husker blot, at jeg stod bag ved en reol med en bog i hånden, sådan som man nu typisk står i en antikva- 
risk boghandel. Udsagnet tænkte jeg ikke nærmere over på anden måde, end at jeg grinede indvendig. Der er sidenhen gået mange år, uden at jeg har tænkt nærmere over det, men i de seneste par år er udsagnet trængt desto mere i forgrunden af erindrede udsagn. Ja, det er i den grad trængt i forgrunden, at det nu for mig er kommet til at stå som ikke mindre end et visdomsord på niveau med "Nosce te ipsum" eller noget i den stil. Vel vidende at kun de færreste vil give mig ret med hensyn til udsagnets aforistiske prægnans, så indeholder det for mig samme karakter af en gåde som hin delfiske udsagn. Men udsagnets betydning er nu ikke helt uafhængig af, hvorvidt det var den støvede og mavesure gubbe Persson, som sagde det, eller den hjertelige og altid imødekommende Greger. Greger går nemlig altid omkring med sit læderforklæde og læsebriller som en skomager. Læsebrillerne hænger altså ikke på næsen (eller rider på panden, eller pendulerer på brystet) fordi han altid rejser sig fra en opslået bog, men altså for, ligesom en skomager, at være præcis i sit håndværk, og måske for nogenlunde præcist at kunne se priserne i sine bøger og ramme de rigtige taster på kasseapparatet. Hvis Greger rejser sig op fra noget, så er det fra boghåndværk, typisk bogbinding, restaurering eller tilsvarende aktiviteter for hvilke hans antikvariat fungerer som skalkeskjul. Greger arbejder med bøger: han binder dem ind, restaurerer, vurderer og handler med bøger i arketypisk forstand: han har bøger mellem hænderne. Men læser han dem? Næppe. Stammer udsagnet fra gubben Persson, så fremstår meningen med vores inskription en kende anderledes. Mit indtryk af gubben Persson er, at han er en distingveret herre, ikke helt ulig en nu mytologisk Frederiksberg-antikvar, med bestemte meninger om litteratur, bøger og mennesker. Ikke desto mindre ville udsagnet lige så godt kunne være kommet fra ham. Gubben Persson sidder altid bag ved antikvariatets skrivebord, som - og det er ikke så almindeligt i et antikvariat - altid er meget nydeligt ryddet. Af håndværk - som hos Greger - er der intet at spore. Gubben Persson var helt og aldeles en tekstens mand, hvis hænder kun er til for at tjene som sokkel for pegefingeren. Og hvis han ikke løftede sit hoved, da han sagde: "Jeg er antikvarboghandler. Jeg læser ikke bøger”, så må han have haft hovedet bøjet over en bog med pegefingeren lokaliseret på et tekststed. Alt andet ville være utænkeligt.

Da jeg selv, for ikke så mange år siden, stod og sludrede med en anden antikvarboghandler og gjorde mig mærkværdig ved at omtale enkeltheder ved mine samlerområder, henkastede denne antikvarboghandler (som jeg husker som stående på den anden side af det altid rodede skrivebord/bardisk med pegefingeren fikseret på et tekststed) distræt et udsagn, som i min hukommelse er blevet hængende som: "Ja, samlerne er de bedste". Underforstået "bedste kunder", men, mistænker man, også den mest overlegne menneskelige livsform i største almindelighed. Men også her er jeg i tvivl om, hvorfra det kommer. Jeg mistænker den altid skummelt smilende antikvar i Aabenhus Antikvariat i Århus (som tydeligvis hedder Hans Aabenhus) eller Thomas Andersson i Uppsala (Antikvariat Boklådan).

Træg som jeg er, var det først efter nogle år, at omfanget, ironien og præcisionen af udsagnet gik op for mig. Det kunne have været en fortalelse fra antikvarboghandlerens side, hvis det ikke var fordi, denne selvfølgelig er klar over, at samlere ikke bare er "de bedste", de er også de mest blinde og de dummeste af dem alle, og at det netop er i deres blindhed og idioti, at de er "de bedste". Det er nemlig kun til 
samlere, at handleren kan sælge en bog til en helt anden pris end til en læser. Når en samler har defineret et samlerområde, så handler antikvarboghandleren med et helt andet objekt end en allerede brugt bog. For hvis det ikke forholdt sig sådan, ville intet antikvariat kunne konkurrere med Kirkens Korshær.

Vi ved det allesammen, men det er netop denne forskel, som træder så tydeligt i relief, når for eksempel Bruun \& Rasmussen i september 2006 annoncerede opdagelsen af et ok pænt eksemplar af andenudgaven af Enten - Eller. Et Livs-Fragment udgivet af Victor Eremita (Kjøbenhavn 1849) med en håndskreven dedikation til H. C. Andersen på titelbladet. Normalt set ville denne, trods alt sjældne, udgave, kun trykt i 500 eksemplarer, koste et par tusinde kroner, hvis man fandt den antikvarisk (hvilket ikke er vanskeligt), men med denne dedikation, som i øvrigt kom til at udgøre det første dokumenterede belæg for kommunikation mellem de to store åndsfigurer i den danske guldalder, vurderedes bogen af Bruun \& Rasmussen til 100.000 kroner og blev den 12. december samme år følgelig solgt til “en europæisk samler” for 170.000 kr. For den pris kan man få samtlige Kierkegaards førsteudgaver hos såvel Lynge \& Søn som hos Vangsgaards Antikvariat og oven i købet i pæne samtidige privatbind. Kierkegaards tekst finder man ganske gratis på nettet eller for en tyver hos sin lokale antikvar.

Alt dette er naturligvis trivielt. Men denne trivialitet tjener ikke desto mindre til at understrege min pointe her, at "den europæiske samler" er en helt og aldeles anden type end "den unge læser", med helt andre interesser og drevet af et helt andet begær. I en vis forstand er samleren en parallelfigur til forfatteren, idet samleren tilskriver bøger værdi gennem samlingens kategorier eller samlingens katalog. Samleren praktiserer altså en form for invers skabelse eller invers tekstproduktion:

$$
\text { SAMLER } \rightarrow \text { BOG } \rightarrow \text { ATTRIBUTION }
$$

som kan jævnføres med 1.1: FORFATTER $\rightarrow$ TEKST $\rightarrow$ LÆSER. Hvor "attribution" eller tilskrivning kan udgøre enhver tekststreng, ved hvilken samleren kvalificerer objektet (bogen) som medlem i mængden collectibles (eller kategori for samlere): "indeholder en tekst af François Rabelais", "omhandler sydnederlandsk landskabsmaleri fra 1500-tallet", "indeholder tekster som er skrevne før eller efter dette eller hint årstal", "er trykt af P.G. Berg", "har været i H. C. Andersens eje", "er trykt i Venedig", "indeholder pornografica", “er sjælden”, "er trykt før 1501”, "indbunden af Gustav Hedberg", "er trykt på pergament", "indeholder billeder af fluer", "er sat med Bodoni-typer", eller hvad ellers samleren måtte finde på af tilskrivninger, som er uden for eller ud over objektets interne tekst. Vi ser da, at samlerens attribution udgør et katalog, i betydningen katá-logos, dvs. en "undertekst" eller en "modtekst", altså en invers tekst som collectible i form af bog som kan skaffes readymade. Det er denne invers-funktion ( $-f$ ) af forfatterfunktionen, som udgør bogsamlerens, eller bibliofilens, logik. Normalt set, som sagt, forestiller vi os, at forfatteren er den, som producerer en tekst, som modtages af en læser, men når læseren holder op med at læse, for i stedet at samle, inverteres den omfangslogiske relation mellem producent og konsument, som forfatter til læser, til en relation mellem samler og attribution, hvor samleren er den til producent transformerede læser, og hvor attributionen er 
et til et objekt tilskrevet forhold (fx en forfatter, at være trykt i Venedig eller tilsvarende). Også denne relation udgør en én-til-mange relation, men nu inverteret $\mathrm{i}$ forhold til relationen mellem forfatter og læser:

$$
\text { ATTRIBUTION }^{\text {leser }} \rightarrow \text { BOG } \leftarrow \text { SAMLER }^{\text {forfatter }}
$$

Omdrejningspunktet, og betingelsen, for en sådan invertering ligger i, at teksten er blevet transformeret til et bogobjekt (eller tilsvarende tekstsupport); i materialiseringen eller virkeliggørelsen af teksten.

Samleren er altså en art negativ eller inverteret forfatter, som producerer attributioner (tilskrivninger i form af modtekster eller undertekster) modsat læsere, som producerer modtagelser og fortolkninger. En samler er en modtager, som ikke modtager det konceptuelle indhold, men blot den materielle support, for i og med denne materielle support, med bog-objektet som hævestang, at skrive en ny tekst, som ostentativt skriver sig ved siden af eller direkte imod forfatterens intention (José Saramagos intention er forhåbentlig ikke at skrive "en José-Saramago for José Saramago-samlere", om end mistanken kan strejfe en kyniker en regnvåd formiddag). Forfatterens intention kan nemlig ikke være i stil med: “er trykt før 1501”, "er sat med Bodoni-typer", "indeholder billeder af fluer" eller tilsvarende. Det kan kun være en samlers - og derved også en forfalskers - intention.
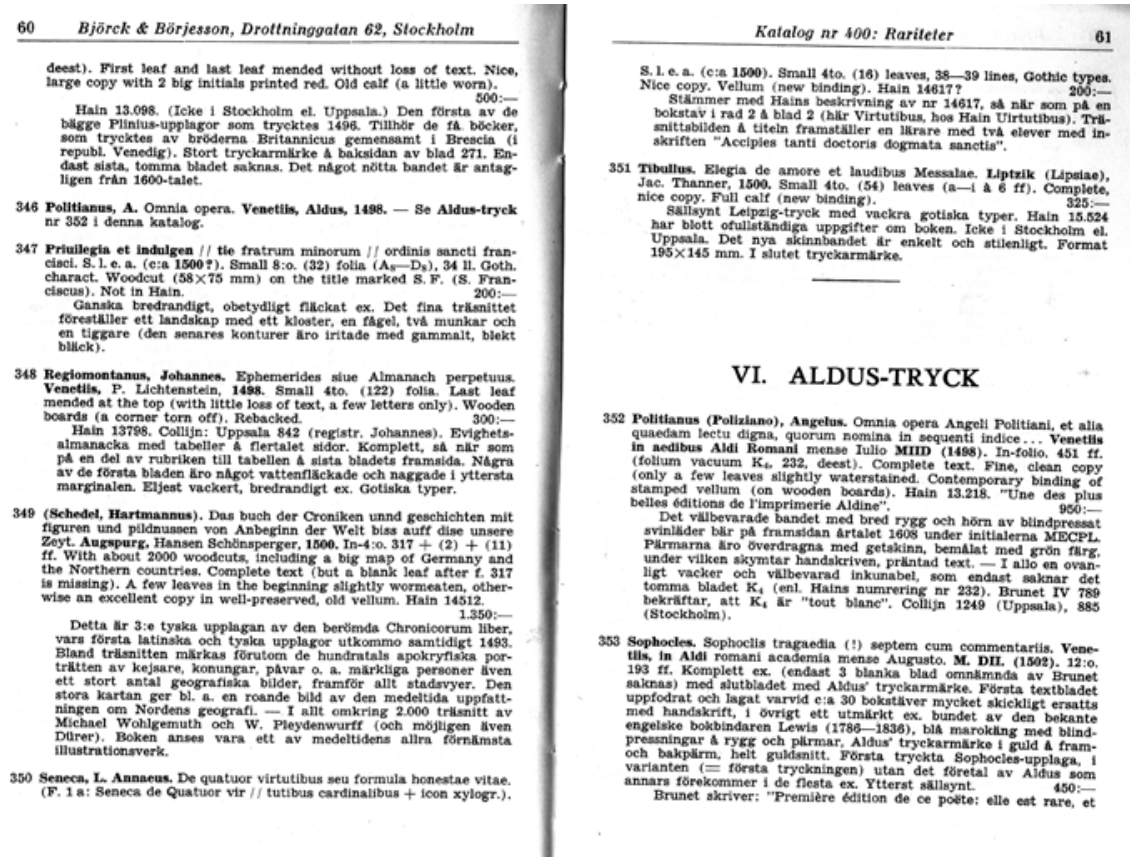

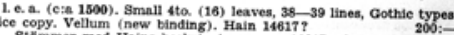

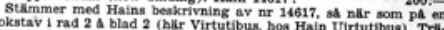

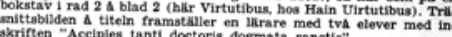
Thbullus. Elegia de amore et laudibus Messalane. Liptrik (Lipsiae),
Jac. Thanner, 1500 . Small fto. (54) leaves (a-i a 6 fft). Complote,
nice copy. Full calf (new binding).

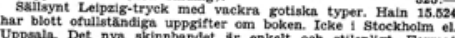
Uppsala Det nya skinnbandet ir enkelt och stlienligt. Forma
$195 \times 145 \mathrm{~mm}$. I slutet tryckarmarke.

\section{ALDUS-TRYCK}

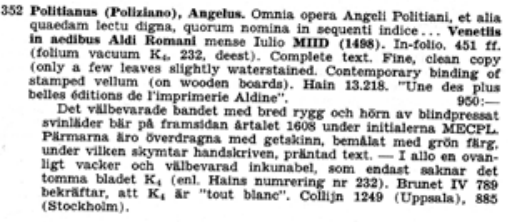

353 s

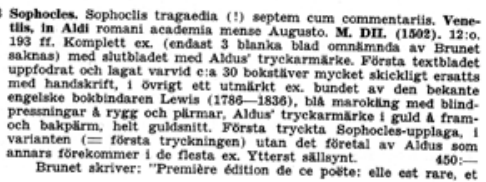

Björck \& Börjesson. Katalog N:o 400. Fyrahundra rariteter. Stockholm 1951.

\section{III: Bogforfalskning, kolofoni og undertekst}

Bogforfalskning er et temmelig underbelyst fænomen, om end betydeligt mere almindeligt end vi normalt går omkring og tror. Bogforfalskning er heller ikke hvilket mange forveksler det med - tekstforfalskning. Da Konrad Kujau solgte sin 
version af Hitlers dagbøger til tidsskriftet Stern i 1983, så taler vi lige så lidt om bogforfalskning som i tilfældet med Denis Vrain-Lucas mange ekstravagante autografforfalskninger, som afsløredes i 1870, og lignende tilfælde. Disse tilfælde af tekstog dokumentfalsk minder mere om den type af forfalskninger, som akademia af og til er plaget af. Men alle forfalskninger har det tilfælles, at de er dokumentfalsk: en forfalskning er et "dokument" (i bredest tænkelige forstand), som udgiver sig for at være udsendt af en producent, fra et sted eller fra en tid, som det ikke er.

At praktisere bogforfalskning behøver ikke at være så vanskeligt, som det lyder. I det lille perspektiv, og på grænsen til overhovedet at kunne kaldes bogforfalskning, er jeg selv sluppet godt fra det ved et par tilfælde. Når man ved, at specielt engelske og amerikanske samlere er meget opsatte på at besidde skønlitteratur i originaludgaver med det originale smudsomslag i pæn stand, så kan det, hvis man er heldig og vælger det rigtige objekt, betale sig at praktisere følgende algoritme: 1) købe et anden- eller tredjeoplag i vilkårlig stand hos en trash-antikvar for ingenting, hvis dette anden- eller tredjeoplag blot besidder et pænt smudsomslag, 2) købe en originaludgave i pæn stand, men uden smudsomslag, i et velassorteret, men noget rodet antikvariat i byens mellemleje, og 3) ud fra disse to bøger at producere henholdsvis en komplet First Edition og en temmelig værdiløs Reading Copy ved at give det pæne smudsomslag til originaludgaven, som manglede et.

Proceduren er formentlig meget almindelig, da det er forbavsende tit, man netop ser førsteudgaver, som ikke er "true firsts" mangle smudsomslag, samtidig med at vanskeligheden i ovenstående algoritme ligger $i$ at finde originaludgavens første oplag uden smudsomslag (det er derfor, det er så vigtigt at vide, hvor man skal lede). Hvis - og det kan jo være tilfældet - der foreligger større eller mindre forskelle mellem smudsomslaget i de forskellige oplag, så er der ingenting at bekymre sig om. Ingen kender disse eventuelle forskelle. Forskelle af denne art bekymrer først handlere i det snobbede segment, når priserne ikke længere kredser omkring de to-trehundrede, men når de begynder overstige 5.000 kroner. Da kan det fx om en førsteudgave af Gravity's Rainbow hedde: "1 of 4000 copies printed in the 1st printing run, and very scarce with an unfaded spine on the 1st issue dustjacket with the $15 \$$ price, the code 0273 on the front flap, and the SBN number in white on the back panel. [...] The price intact dustjacket is crisp, clean, unfaded, with no tears, no chips, no soiling, no wrinkles, no folds." Alt andet lige, hvis man som samler er ligeglad med "code 0273" og tilsvarende, kan man få bogen til en pris betydeligt under de \$2,650, som ovenstående var til salg for. Men denne samler vil uvægerligt græmme sig, når hans konkurrerende samler viser sit "code 0273"-eksemplar ved næste Rare Book Collectors' Annual Convention eller tilsvarende.

Bogforfalskning er, som al forfalskning, altid også dokumentfalsk. Den mest effektive måde at forfalske en bog, som også udgør bogforfalskningens andet yderpunkt (grænsende til autografforfalskning slet og ret), men som får dens værdi til at øges mere end betragteligt, er, hvis forsatsen er forsynet med en forfatterdedikation. Denne type kontrafaktisk historieskrivning lader sig også fint udføre på andenudgaver uden smudsomslag, hvilket auktionspriser bekræfter. Enhver habil tegner, som har gjort sit hjemmearbejde ordentligt, ville snildt kunne fabrikere en mængde meget spændende (for den ambitiøse) eller mindre spændende (for den mere nøj- 
somme forfalsker) dedikationer, som ikke kun vil holde for enhver eksperts blik, men også for enhver teknisk undersøgelse. Kuriøst nok har jeg selv aldrig hørt tale om denne type af forfalskning, hvilket er bemærkelsesværdigt, da den giver betydeligt større afkast på en meget lille indsats. Men derfra til at konkludere, at det ikke forekommer, ville være mere end utilladeligt naivt. Vi ved fx, at signerede bøger af Thomas Bernhard er (dvs. var) relativt sjældne. Ikke desto mindre, og uden krav på videnskabelighed, så må vi konstatere, efter at have fulgt markedet nu i et årti, at signerede bøger af Thomas Bernhard tilsyneladende bliver mere og mere almindelige, samtidig med at antikvarboghandlere bliver ved med at lægge standardfrasen: "Signierte Bücher von Thomas Bernhard sind sehr selten" til katalogposten, som nu forekommer i en sådan mængde, at det hele forekommer fuldstændig grotesk (foretag en søgning på zvab.com, og I vil forstå, hvad vi mener). Uden at mistænkeliggøre følgende post (hvis nogen skulle føle sig fristet):

Wittgensteins Neffe. Eine Freundschaft. (4. Auflage). Frankfurt am Main, Suhrkamp, 1984, $8^{\circ} .163$ S., 6 Bl. OPp. mit Original-Schutzumschlag. Bibliothek Suhrkamp 788. - Titel mit eigenh. Signatur und Datum "Thomas Bernhard | 4. 10. 84." - Signierte Bücher von Thomas Bernhard sind sehr selten und gesucht.

så bør vi holde os for øje, at bare signaturen betinger 1.170 af de 1.180 euro, den er til salg for. Som samler bør man i hvert tilfælde spørge sig selv, hvorvidt man er bogsamler eller autografsamler.

Fra kunstverdenen ved vi dog af bitter erfaring, at hvis der pludselig dukker et objekt op, som typisk påstås at have eksisteret i al ubemærkethed i en eller anden provinsiel privat samling (hvilket er en pæn måde at sige, at det savner proveniens), som giver forskere et "missing link" i deres teorier, $\mathrm{fx}$ en forbindelse mellem den tidligere og den senere Vermeer (van Meegeren), en forbindelse mellem aben og mennesket (Piltdown-manden) eller en forbindelse mellem to førende åndsfigurer i et lands guldalder, så bør det kritiske sind automatisk slå om på Alarmstufe Rot, som vores tyske naboer ville udtrykke det. Dette sker dog aldrig på bogmarkedet, så jeg vil trygt opfordre den fattige forfatter (som typisk behersker sine hjemmeopgaver) til at prøve lykken. Lidt turèlliana, måske?

Optagetheden af originaludgaver og dedikationseksemplarer er faktisk en relativt ny ting. Fra renæssancen og lang tid fremefter var man først og fremmest interesserede i udgavens kvalitet. Denne diskussion om udgavens kvalitet gennemsyrer stadigvæk hele Brunets bibliografi (J. -Ch. Brunet, Manuel du Libraire et de l'Amateur de livres I-IX, som udkom i en række udgaver gennem hele 1800-tallet). Brunet angiver, hvorvidt det er en editio princeps, om det er den "første tyske edition" eller tilsvarende, men det som først og fremmest spiller med, når det gælder bogens værdi, er, hvorvidt det er en "bonne édition", eller om den er "peu estimée"; om det er en god edition af teksten, eller om det drejer sig om en inferiør udgave af den.

Denne "First Edition Mania", kan man argumentere, spredtes først af den amerikanske boghandler og bibliograf Thomas J. Wise, som i et par artikler i tidsskriftet The Booksman fra 1894 i en ophidset meningsudveksling med mere konservative boghandlere og bibliografer ikke bare argumenterede med den kendsgerning - ved 
at gennemgå til hvilke priser hvilke udgaver blev solgt for - at samlere faktisk efterstræber originaludgaver, fordi det er originaludgaver, men også fordi originaludgaver inkarnerer en litteraturhistorisk værdi, som er større end senere udgavers. $\mathrm{Nu}$ ville end ikke Wise argumentere for, at 1973-udgaven af Gravity's Rainbow havde hverken større eller mindre litteraturhistorisk værdi end 1991-oplaget, da de teknisk set udgør to forskellige impressioner (oplag) af samme edition (udgave). Det, Wise talte for, var værdien af alle de efemere tryk, som engelske forfattere i 1800-tallet, som typisk først publiceredes i tidskrifter, lod trykke som særtryk i pamfletform: "A guide to such ephemera would be of the utmost value to dealer and collector alike." Citatet har jeg fra Carter og Pollards klassiske An Enquiry into the Nature of Certain Nineteenth Century Pamphlets fra 1934.

Det, som John Carter og Graham Pollard viste, med overordentlig skarp bibliografisk metodik, var nu blot det, at når Wise skrev dette, så havde han gennem lang tid - formentlig allerede fra slutningen af 1870erne - været særdeles aktiv med selv at producere denne type af særtryk og selv at handle med disse tryk til begærlige samlere af Modern Firsts, hvilket bekræftede den tese, at det ikke er samlingsområder, som producerer forfalskninger, men forfalskninger som producerer samlingsområder, på samme måde som det ikke var dedikationseksemplarer som producerede forfalskninger af dedikationer, men forfalskninger af dedikationer som producerede samlere af dedikationseksemplarer. Hele denne historie om Thomas J. Wise-forfalskningerne skal ikke genfortælles her, ej heller Carter og Pollards mindst lige så fascinerende afsløring. Men det, jeg ikke kan lade være med at nævne, er, at man falder baglæns over beundring for såvel det konceptuelle hjemmearbejde, som Thomas J. Wise har lagt $i$ at producere troværdige (alternative) historier for de hidtil ukendte tidligere udgaver af Shelleys, Ruskins og andres værker, som - i særdeleshed - det tekniske arbejde, som hans kumpan Harry Buxton Forman stod for, at producere de fysiske pamfletter med alt, hvad det indebærer. Det hele er så godt gjort, at det i sandhed er mere overraskende, at Carter og Pollard overhovedet fattede den mistanke, som var nødvendig for at motivere den enormt omfattende bibliografiske og tekniske undersøgelse af materialet (for dem drejede det sig om tyve års intensivt og møjsommeligt detektivarbejde), end at vi den dag i dag stadigvæk skulle være uvidende om hele projektet. Den energi og ihærdighed, som Wise og Forman lagde i deres forfalskninger, er så imponerende, at det er svært at forestille sig, at denne type af forfalskning ikke er et historisk unikum. Men ikke desto mindre findes der et mindre antal tilsvarende tilfælde af rigtig godt udførte forfalskninger af hele editioner.

Da Frederic Prokosch, en amerikansk forfatter og bogsamler, i 1968 arrangerede salget af sit litterære arkiv, henvendte han sig til Sotheby's, hvor selvsamme John Carter ironisk nok blev sat på den opgave at undersøge og vurdere Prokoschs bøger. Denne gang fattede Carter dog ingen mistanke, og i løbet af de følgende år blev større og mindre portioner af Prokoschs bøger med regelmæssige intervaller solgt på auktion. Bøgerne, som snarere var små pamfletter, blev kaldt sommerfuglebøgerne på grund af deres lille format og lyse marmorerede papiromslag og indeholdt dels Prokoschs egne tekster, dels tekster af forfattere, han beundrede, såsom W. H. Auden, Christopher Isherwood, T. S. Eliot og mange andre. I 1972 blev et komplet 
sæt af disse sommerfuglebøger solgt til den berømte London-baserede antikvarboghandler Bernhard Quaritch. Hos Quaritch begyndte man dog at fatte mistanke om bøgernes ægthed. Man hyrede da den berømte bibliograf Nicolas Barker til at undersøge dem, og det lykkedes også for Barker, efter en omgang møjsommeligt bibliografisk detektivarbejde, at bevise, at mange af bøgerne var blevet trykt langt efter deres angivne impressum.

62

DRittellateinijd)e Sitteratur

Neckam), 2) Alter Aesopus (Baldo). 3) Novus Avienus. Fcruter bes Miattfăแ Bin , A ld a' (Ente bes XII. Jahrbuntort\$).

289. $\mathrm{M}$ a x i mian i Elegiae. Ad fidem Codicis Etonensis recensuit / M. Petschenig. Berolini, Calvary, 1890 (in gr. $8^{\circ}$; 1 Bl. [praefatio] \& 38 pp.).

Der zu grunbe gelegte Eober gebört Dem 11. Jahrbunbert an.

290. Early Mysteries, and other Latin Poem s of the twelfth and thirteenth Centuries: edited / by Thomas Wright / London, Nichols, 1838 (in gr. $8^{\circ}$; XXX \& 136 pp.).

Mit Debiłatiou Des ફ̧erausgebers an Dr. Sutuzel.

291. REINARDUS VULPES. | Carmen epicum seculis IX et XII conscriptum. Ad fidem Codd. Mss. edidit / Franciscus Josephus Mone. Edidio princeps. Stuttgardiae \& Tubingae, Cotta, 1832 (in gr. $8^{\circ}$; VIII \& 338 pp. +1 Bl. [Druckfehler]).

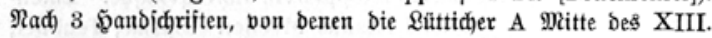

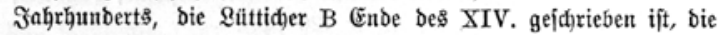
Barijer ebenfalls im XIY. Jabrgumbert.

292. Petri ABAELARDI abbatis Ryenfis et $\mathrm{Hel}$ o is a a abbatiffae Paracletenfis e pistola e/a prioris editionis erroribus purgatae \& cum Cod. Ms. collatae curâ Ricardi Rawlinson / Londini, Currl \& Taylor, MDCCXVII (in gr. $8^{\circ}$; VIII \& 280 pp.).

293. Briefwedifel swildhen Hbaelard und Feloile/ Hus dem Cateinilden überleţ̧t / von Dr. p. Baumgärtner. Ceipz̧ig, Reclam, [1894] in kl. $8^{\circ}$; 316 pp.).

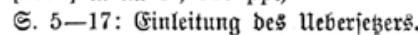

294. Policratici Contenta. | feftivū opus: et omni Itatui delecta-

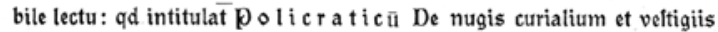
philolophorum Joanis Salelberienlis doctillimi lane et eloquêtiflimi viri / Quod quidē opus libris octo digeltum ett / Venale in vico fancti Jacobi in Sole aureo: et in Kilio aureo apud benix volos mercatores mgr̄m Bertholdū Rēmbolt: et Joānē parvū. [in fine:] Inpressum Parrhifiis / Anno domini M. D. XIII. Die vero XXV. May.

Эn quartīörmigen $8^{\circ} ; 46$ Bl. [Borîtüđe] \& CCXXII gež. $\mathfrak{B l}$.).

Eduard Grisebach. Weltlitteratur-Katalog. Mitt literarischen und bibliographischen Anmerkungen .

... Dritte Auflage. Berlin 1913.

Det er også denne formulering: "deres angivne impressum”, som giver os nøglen til logikken bag fænomenet bogforfalskning. I en fascinerende artikel, "False statements in 15th-century colophons" (Myers/Harris, eds., Fakes and Frauds, Oak Knoll Press, 1989), diskuterer Lotte Hellinga det omstridte spørgsmål om dateringen af Catholicon (GW 3182), som i og for sig er af afsindig stor betydning for bogtrykkeriets tidligste historie i almindelighed og Gutenbergeriet i særdeleshed, men dette interesserer kun os lægmænd perifert, eller skal vi sige: epigrafisk. Mere interessant er diskussionen om kolofoner i almindelighed. Med udgangspunkt i kolofonen for en af de første udgaver af Johannes Mandeville. Itinerarium [Gouda. Gheraert Leeu, c. 1483-84], som påstår, at bogen er trykt i Venedig (... quibus impressum vides venetica monstrant manifeste), og hvor enhver inkunabulist også let ser, at den rent 
faktisk er trykt med venetianske typer, men som ikke desto mindre, på baggrund af andre kendsgerninger, bevisligt stammer fra Gheraert Leeus trykkeri i Gouda, går hun over til at diskutere kolofonens, eller impressumets, væsen i det hele taget. Det viser sig hurtigt, at de fleste kolofoner farer med usandheder: under bogens tidligere historie angiver impressumet forbavsende langt fra altid bogens faktiske oprindelse. Men fænomenet er ældre end bogtrykkerkunsten. Curt Bühler havde tidligere (i "False Information in the Colophons of Incunabula", Proceedings of the American Philosophical Society, vol. CXIV (1970), pp. 398-406) henvist til "utallige" eksempler på falske impressum såvel under inkunabeltiden, som før trykkerkunstens opfindelse. I manuskripters kolofoner fandt han datum som den 30. februar, den 33. marts, den 31. juni samt et hav af andre "unævnelige" friheder med hensyn til den romerske kalender. Altså på ganske samme måde som vi, som er bevandrede i pornografika, heller ikke forbavses over trykkesteder som "Cythere", "Utopia", eller ligesom vi godt ved, hvad vi kan forvente af en tysk eller engelsk bog, hvis impressum angiver "à Paris".

Det er nemlig pointen - også Hellingas pointe, inden hun helt når at fortabe sig ned i Catholicon'ens spidsfindige bibliografiske ejendommeligheder - at en kolofon, som: "et udsagn tilskrevet en tekst, som giver omstændighederne omkring tekstens skabelse eller produktion, er en tekst på egne præmisser, og som derfor er åben for interpretation med hensyn til tid, sted og omstændigheder for dens oprindelse, som enhver tekst er."

Vi ser da, at det, samleren (ligesom forfalskeren) gør, er, at han producerer konceptuelle, men indexerede og katalogiserbare - "kolofon-tekster" til bog-objekter (svarende til hvordan forfalskeren producerer objekter, som svarer til samleres "kolofoner"):

$$
\mathrm{SAMLER} \rightarrow \mathrm{KOLOFON} \leftarrow \text { OBJEKT }
$$

og at denne produktion, som altså fuldstændigt er på niveau med en forfatters produktion, udgør attributionen af det readymade (allerede-gjorte) objekt som element i mængden collectibles. Eller rettere sagt: collectibles (kategori for samlere) er en selvhæftende operator ved samlerens kolofoni (attribuering eller tilskrivning); kolofonien er netop denne inverse tekstproduktion, som vi kunne iagttage i middelalderens manuskripter og tidligmoderne tryk, for at ikke tale om Modern Firsts og dedikatonseksemplarer. Hellingas (korrekte) formulering af Mandevilles Itinerarium, som "Johannes Mandeville. Itinerarium [Gouda. Gheraert Leeu, c. 1483-84]" er et tydeligt eksempel på just denne kolofoni. Den er nemlig uden for eller mod selve teksten. Oplysningen om, at det drejer sig om Johannes Mandevilles Itinerarium står i tryksagens egen kolofon: "Explicit itinerarius a terra anglie [...] a domino johanne de mandeville milite suo auctore". Da samleren - her Lotte Hellinga - afviser tryksagens egen attribution af sig selv som "fra Venedig", producerer hun i stedet en ny kolofon (dvs. en ny attribution og en ny katá-logos): "[Gouda, Gheraert Leeu, c.1483-84]", inden for kantede parenteser og i en separat tryksag som sig hør og bør (ikke fx med blækpen på titelbladet, som man stadigvæk kan se i ældre bøger, at bibliografer fra det 19. århundrede gjorde). Men som tekstproduktion er det lige- 
gyldigt, om bibliografen videregiver sin katá-logos, sin under-tekst, som selvstændig publikation eller som tilskrift til det således attribuerede objekt, produktionen af (under-)tekst er den samme.

\section{IV: Den ulæselige bog}

Vender vi tilbage til vores Nosce te ipsum, hin distræte antikvariske visdomsord, og ser på disse to udsagn samlet; på den ene side: “Jeg er antikvarboghandler. Jeg læser ikke bøger”, og på den anden side: “Ja, samlerne er de bedste”, så ser vi også to typer af kunder eller to typer af mennesker: læsere og samlere. Hvis antikvarboglader kan anskues som et mikrokosmos, hvilket er en ikke helt igennem urimelig antagelse, så består verden - sub specie æternitatis, som er antikvarboghandlerens position - af to typer af mennesker: samlere og læsere, bevarere og forbrugere, materialister og idealister. Man kan også sige, at verden, altså i dette mikrokosmos, består af to forskellige typer af ting: reading copy på den ene side og en collectible på den anden; faktisk de to ting, vi selv producerede ved vores lille fidus med smudsomslaget. Men i grunden er det temmelig bemærkelsesværdigt, at disse to typer af mennesker og objekter overhovedet kan eksistere i et og samme kosmos, i en og samme orden; bøgernes orden. L'ordre des livres var også titlen på Roger Chartiers bog fra 1992, som for bibliografien og boghistorien er kommet til at markere et skift i bogstudiet fra forfatter, trykker og produktion af bøger mod et større fokus på læser, distribution og marked for tryksager. Læseren var gennem lang tid en temmelig arbitrær figur i forhold til forfatteren og bogen, og det med god grund.

Da William Caxtons bio- og bibliograf William Blades publicerede sin lille bog om biblioklasme The Enemies of Books (1880) gennemgik han alle tænkelige måder, hvorpå bøger er blevet ødelagte. Blades gennemgår alt fra "ild", "vand" og "gas og varme", over "støv og vanrøgt", "uvidenhed", "bogorme og andre insekter", for afslutningsvis at behandle "bogbindere" og "samlere". Typisk for sin tid, så glemte han måske den værste biblioklast af dem alle, nemlig læseren. Bøger går, som vi alle ved, først og fremmest til grunde af brug. Dette er et forhold, som gælder alle collectibles. En collectible er en ting, som kan skaffes already made. En tekst kan ikke skaffes readymade i anden form end netop en bog, et manuskript, en lydoptagelse eller tilsvarende. En tekst kan derimod opføres; det er mere, end hvad en bog kan. En bog kan udstilles, og hvis man virkelig vil være ven med bogen, dvs. bibliofil, så er det faktisk alt, hvad den kan. Det er dette, som gør et hvilket som helst objekt til en collectible: det vil sige en ting, som man trækker ud af den almindelige cirkulation af ting for at placere den som en særlig ting vendt mod evigheden, kun med det formål, at den skal ses på. En collectible er, som Krzysztof Pomian har vist i sin Collectionneurs, amateurs et curieux (Paris 1986), det, som kun skal være synligt og i denne udstillede synlighed agere som budbringer for det usynlige; for det, som vi ikke kan se, for det, som befinder sig hinsides vor rumlige eller tidslige horisont. Det modsatte af en collectible er en reciprok readymade. En reciprok readymade er at bruge en collectible til et eller andet, fx at bruge en Rembrandt som strygebræt, pergamentblade fra middelalderen til bogbind eller bogsider til toiletpapir. At teste en collectibles reciprocitet, eller gensidighed, er nok det værste, man kan udsætte 
en samler for. Blades var ikke så lidt oprørt over at se Caxton-tryk blive brugt som toiletpapir, Arne Magnussen morede sig tilsvarende slet ikke over at se islændinge bruge sine håndskrifter til at sigte ost. Historierne om brug af bøger til alt fra kræmmerhuse til bogbind er utallige og omtales altid med en vis skrækblandet fryd i små stilfulde bøger-om-bøger sat i Garamond, Jenson eller en anden renæssanceantikva og trykt på bøttepapir. Det, som samlerne ikke gerne taler om, er også den absolut hårdeste test af reciprociteten, nemlig at udsætte objektet for det, det oprindeligt var beregnet til, nemlig læsning og brug. For Pomian er det modsatte af en collectible (eller semiofor, som han kaldte det) en brugsgenstand. Brug og tegn er to inkommensurable størrelser i et objekt. Jo mere brugsværdi et objekt har, jo mindre tegnværdi har det, og omvendt. Og da en collectible kun har tegnværdi, så giver det sig selv, at så kan den ikke have nogen brugsværdi. At bruge en collectible i henhold til dens originale intention ville være at devaluere dens tegnværdi. Da ser vi også klart, at det ikke er en tilfældighed, at biblioteker ikke låner deres skatte ud, at de bliver udstillet i glasmontrer, at de bliver reproduceret som faksimiler og tilsvarende manøvrer for at undgå brug. Bøger, som er blevet til collectibles, må ikke læses. Det er lige så slemt - for at ikke sige slemmere - end at bruge dem til kræmmerhuse eller til at sigte ost.

Det mest sikre tegn på en samler ser man, når denne holder en collectible i sine hænder, sammenlignet med når han holder andre bøger (fx opslagsværker om collectibles); se bare på den fjantede måde med hvilken samleren åbner bogen, som var ryggen ved at revne, hvad øjeblik det kunne være, som var siderne ved at pulveriseres til støv ved mindste uforsigtige bevægelse; samleren holder om sin collectible, som var det en mumie fra antediluviansk tid. Skrækscenariet for samleren - som i øvrigt alle samlere har været ude for, når de i overmod er kommet til at invitere en ignorant til deres bibliotek - er, når denne ignorant så selvfølgeligt og frejdigt spørger: "Den ser spændende ud, kunne jeg monstro låne den?”, hvilket jo ret beset er et naturligt spørgsmål efter en længere beskrivelse af et objekts fortræffelighed. Eller, og det er endnu værre: læseren bliver interesseret i objektet og ligesom strækker hænderne ud for selv at kigge nærmere på objektet. For samleren ligger der i denne situation betydeligt mere horror end i alle af Fernand Drujons listede bogbrændinger sammenlagt (Essai bibliographique sur la destruction volontaire des livres ou Bibliolytie. Paris 1889 og Destructarum Editionum Centuria. Paris 1893).

\section{V: Den autoritetsløse forfatter}

Hvis De, som læser dette, er kommet så langt ind i teksten, som De faktisk er, hører De til en langt mindre og - tilsvarende - desto mere ombejlet minoritet, nemlig minoriteten af læsere. Problemet med litteratur (og kunst) er ikke et kvalitativt problem: der bliver skrevet et hav af fremragende tekster i alle mulige og umulige genrer; problemet med litteratur (og kunst) er heller ikke et kvantitativt problem, i den forstand at der mangler tekster: for hvert år øges verdens samlede tekstproduktion eksponentielt i forhold til de foregående år. Nej, tekstens (og kunstens) problem er snarere af algebraisk art: det ligger i forholdet mellem forfatter og læser. Forholdet 
mellem kunstproducent og kunstkonsument er nu så forskubbet, at det efterhånden er vanskeligt at skaffe læsere og konsumenter til alle de tekster, som produceres.

Dette forhold bør også give enhver Schriftsteller, som bare har et nogenlunde reflekteret forhold til sin aktivitet, anledning til eftertanke. En af de bedre tanker, som på det seneste er udkommet som bog, er den spanske forfatter Enrique Vila-Matas Bartleby et compañia (Barcelona 2000), som er en overordentligt underholdende udstilling af forfattere, som stræber efter at finde måder, hvorpå de kan lade være med at skrive. Men hvad vil det sige: en forfatter som lader være med at skrive, men som insisterer på forfattergerningen? Svaret ligger måske hos læseren, som er blevet desto mere interessant, jo mere sjælden hun er blevet. Symptomatisk er det således, at Jorge Luis Borges' gamle oplæser Alberto Manguel forfattede en bog om læsningens historie (A History of Reading. Harper Collins 1996), og symptomatisk er også afhandlinger med titler som "A Living Library: The Readings and Writings of John Dee" (senere publiceret som William H. Sherman: John Dee. The Politics of Reading and Writing in the English Renaissance. Amherst 1995). Fokus er allerede begyndt at skifte med Chartiers L'ordre des livres, men omfanget af dette fokusskift er først blevet virkelig åbenbart med den digitale teknologis peer-to-peer (P2P) applikationer og omgangen med dynamiske tekster (typisk databaser) uden faste læser- eller forfatterpositioner. Omlægningen er først og fremmest karakteriseret ved, at læserog forfatterpositionen smelter sammen til én og samme position: producent og konsument på én gang. Denne læser-forfatter eller forfatter-læser producerer og/eller konsumerer én eller flere tekster, samtidig med at én tekst (et tekstmateriale eller en teksthændelse) har flere forfatter/læser-positioner. Lad os derfor herefter kalde denne sammenvævede position af lector og auctor for "textor":

Populært vil man definere en sådan relation mellem textor og tekst, eller en peerto-peer relation, som en "mange-til-mange-relation". Men en mange-til-mange-relation er en logisk håbløshed (det er ikke andet end en mængdes potensmængde). Hvis vi vil forstå forholdet mellem textor og tekstmaterialet eller teksthændelsen (bogen, samtalen eller internetsiden), så må vi se på den "relationsentitet", som forbinder disse to entiteter:

$\mathrm{TEXTOR} \rightarrow[\mathrm{X}] \leftarrow$ TEKST

Forholdet er et tilskrivende eller attributivt forhold (X) mellem på den ene side et subjekt, som interagerer med teksten (altså en læser, forfatter eller tilsvarende), som står i en en-til-mange-relation til dette attributive forhold, og på den anden side teksten, som tilsvarende står $i$ en en-til-mange-relation til samme tilskrivende forhold (X). Vi ser da hurtigt, at de "traditionelle" forhold, "er forfatter af" og "er læser af", langt fra svarer til de mulige måder at omgås tekster på. Forhold som at et subjekt "kommenterer" en tekst, " påbegynder" en tekst, eller "raderer" en tekst, er lige så relevante med hensyn til tekstmaterialer og teksthændelser som "skrevet af" eller "læst af". 
Vi ser nu også ganske uproblematisk, at samleren, handleren og bibliografen alle er en form for textor af en collectible. Samleren, handleren og bibliografen er faktisk ikke andet end en textor af en attribution til et objekt (et tekstmateriale eller en teksthændelse), og det er netop denne "tilskrivning" - denne attributive tekststreng - som definerer objektet som collectible. Da forstår vi også bedre Louis Jacob de Saint-Charles' definition af bibliografi som "skrivning og afskrivning af bøger":

TEXTOR $^{\text {-forfatter }} \rightarrow$ OBJEKT $\leftarrow$ ATTRIBUTION ${ }^{\text {tekst }}$

Samtidig forstår vi nu også bedre antikvarboghandlerens nosce te ipsum: "Jeg er antikvarboghandler, jeg læser ikke bøger”. Antikvarboghandleren, ligesom samleren eller bibliografen, står slet ikke i nogen relation til forfatterens eller læserens tekst. Den tekst, som handleren forholder sig til, er objektets tilskrift (dets "kolofon", så at sige). Handleren er interesseret i tekststrenge som: "er ejet af", "er trykt af", "indeholder alle originale plancher", men også i tekststrenge som "er skrevet af", "omhandler" og lignende. Tilskriften, eller attributionen, er samlerens eller bibliografens "tekst". Det attribuerede "objekt" behøver heller ikke at være et fysisk objekt; en bibliograf beskriver typisk en edition eller en impression som en imaginær "ideal copy", og der ligger intet til hinder for, at bibliografer eller samlere beskriver ikke længere eksisterende objekter (Rosenkrantz' katalog), fiktive objekter (Fortsas' katalog) eller objekter, som ikke kan eksistere (alle katalogers mange ghost editions). De fleste bibliografier indeholder rent faktisk denne type af tilskrivninger. Hvis man vil trække det hårdt op, ville man også kunne sige, at bibliografier eller katalogtekster ikke er andet end en form for imaginær objektproduktion. Bibliografer og andre katalogskribenter producerer faktisk det, som svarer til et sæt af kolofoner uden tilhørende tekst. Eller sagt på en anden måde: attributive forbindelser til vilkårlige objekter. Handlere, bibliografer, samlere og katalogskribenter producerer rent faktisk relations-entiteten "objekt", ved hjælp af elementer som "skrevet af", "illustreret af", "ejet af" og tilsvarende. Det er også disse objekter, som former samlernes, handlernes og katalogskribenternes kategorier, og som transformerer objektet - her tekstmaterialet eller teksthændelsen - til en readymade collectible.

En anekdote vil illustrere denne pointe og samtidig understrege virkeligheden og (virksomheden) af denne samlerens og bibliografens kolofoni. Det hændte i sommeren 1840, da 132 kendte bogsamlere over hele verden modtog et lille tyndt katalog med titlen: Catalogue d'une très-riche mais peu nombreuse Collection de Livres provenant de la Bibliothèque de Feu M. Le Comte J. N. A. de Fortsas, Dont la vente se fera à Binche, le 10 août 1840 .... I dette katalog annonceredes en auktion af en vis grev Fortsas' bemærkelsesværdige bogsamling efter dennes død 1839. Auktionen ville finde sted i Binche, en by i det sydvestlige Belgien, den 10. august 1840 . Bogsamlingen var lille, kataloget listede blot 52 poster, men hver post var på den anden side et unikum. Grev Fortsas samlede nemlig kun på unika. Kunne greven - meddeler katalogets forord os - lokalisere yderligere et eksemplar af en af sine bøger, gjorde han det umiddelbart af med det. På den måde fik grev Fortsas opbygget en samling af bøger helt og aldeles ukendte for bibliografer. For de 132 udvalgte bibliofiler må kataloget have forårsaget en ikke ubetydelig tirring af deres - må vi 
da gå ud fra - veludviklede collectitis. I det mindste så ankom de op til auktionens dato i betragteligt antal til Binche. Da de hver for sig forsøgte at lokalisere notaren Mourlons kontor, 9 rue de l'Église, hvor auktionen skulle finde sted, kom de dog til at lede forgæves. Nogen notar Mourlon fandtes ikke i Binche, heller ingen gade ved navn "Rue de l'Église". Også den afdøde greve Fortsas var helt og aldeles ukendt blandt Binches borgere. Men på dagen, da auktionen skulle finde sted, var der pludselig plakater at læse rundt omkring i byen, hvor det blev tilkendegjort, at auktionen var aflyst, da byen Binche havde skaffet hele samlingen til dens offentlige bibliotek. Man kan levende se rædslen i samlernes ansigter for sig. Da de skuffede bibliofiler så forsøgte at se deres desiderata i kommunens bibliotek, erfarede de hurtigt, at der slet ikke fandtes et offentligt bibliotek i Binche. For dem, som endnu ikke havde fattet det, så stod det nu klart, at de havde været offer for en practical joke. Bibliofilerne forlod Binche tomhændede, men, mistænker vi, dog med den trøst, at heller ingen anden ville få hænderne i deres respektive desiderata rarissima.

Siden hen blev det afsløret, at det var en pensioneret officer og numismatiker ved navn Renier Hubert Ghislain Chalon, som havde gennemført denne practical joke fra start til slut, og verden over den dag i dag fejrer bibliofiler hændelserne i Binche 1840 på bibliofilers særlige måde: nemlig ved at skrive lærde bibliografiske afhandlinger om fiktive biblioteker - indledt af Gustave Brunets "Essai sur les Bibliothèques Imaginaires" (pp. 297-390 i Bibliophile Jacob [Paul Lacroix]: Catalogue de la Bibliothèque de l'Abbaye de Saint-Victor au seizième siècle, rédigé par François Rabelais, commenté par le Bibliophile Jacob et suivi d'un Essai sur les Bibliothèques Imaginaires par Gustave Brunet. Paris: J. Techener 1862) - og, frem for alt, genoptrykke kataloger i et hav af limiterede, pragtindbundne og privattrykte bibliofil-udgaver. Thi en vis belønning fik de narrede bibliofiler alligevel med sig hjem. Kataloget, som de havde fået tilsendt, er naturligvis siden gået hen og blevet noget af en bibliofil raritet. Således er et eksemplar af den originale pamflet i skrivende stund til salg hos James Cummins Bookseller i New York til \$3.500.

\section{VI: Den post-autoritære litteraturs form}

Det burde ikke være svært at se ligheden mellem Chalons practical joke og Lawrence Weiners konceptkunst. Da Weiner havde set, at kunst først og fremmest drejer sig om dåbshandlingen af et materiale eller en handling til "kunst", og derfor ville undersøge, hvad denne attribution eller tilskrivning egentlig er, gør eller betyder, så var det ganske eksakt samme type af undersøgelse, som Chalon iværksatte med sit 
katalog, nemlig det ofte glemte forhold, at en post i et katalog er "en tekst på egne præmisser, og som derfor er åben for interpretation med hensyn til tid, sted og omstændigheder for dens oprindelse, som enhver tekst er" (Hellinga).

$\mathrm{Nu}$ forstår vi bedre, hvorfor hin antikvarboghandler sagde, at han ikke læser bøger, fordi han er antikvarboghandler. En antikvarboghandler - ligesom i øvrigt også en forsker, en forfalsker eller en samler - væver, læser og skriver kolofoner. Kolofonen er det katá-logos som produceres ved en attribution af et objekt. Denne tekst kan være temmelig immateriel, som fx "[Gouda. Gheraert Leeu, c.1483-84]" (det ville være gubben Perssons katalog); men denne tekst kan også være meget mere fysisk, end konkret poesi nogensinde vil kunne blive, som $\mathrm{fx}$ at restaurere et 1700-tals bind, udskifte smudsomslag eller applicere dedikationer på forsatsen (af hvilke i det mindste det førstnævnte ville være Gregers katalog). Fælles for dem begge - gubben Persson og Greger - var, at de stod med hånden eller fingeren på noget, da de distræt ytrede deres visdomsord. Det afgørende her er ikke objektet, de pegede på, men selve pegningen. Det er også denne pegefinger, eller dette index, som tydeligst beskriver den materialitet, som er tilbage, når objektet er fjernet.

og da textoren (bibliografen, samleren eller handleren) som sagt er en negativ forfatterfunktion, ligesom kataloget er en mod- eller undertekst, så ser vi, at "indexet" udgør en invertering af objektet (collectible). Eksistensen og virksomheden af dette index, eller denne pegefinger, betyder også en del for samleren og samleriet. Såvel Weiners kunst, Jelineks Neid, som Chalons hændelse forholder sig direkte til "konsumeringen" af værket, og de vender sig imod det fysiske ejerskab - som også er dyrt, immobilt og en stadig kilde til bekymringer - for i stedet at pege på et fattigt, let og mobilt "ejerskab", som er det katalogiserende eller bibliografiske ejerskab. Ved den egne produktion af under- eller modtekster fremstiller man sine egne kategorier i form af de kolofoniske tekststrenge, som forbinder objekter eller hændelser med "verden". Det er selvfølgelig Duchamps værker, som er skarpest her. Den venlige ironi i Duchamps svar til Gorsline er ikke til at tage fejl af. Når Gorsline står med et grimt, tungt og ubrugeligt objekt mellem sine hænder, og Duchamp svarer, at signeret eller ej har dit fund: "samme 'metafysiske' værdi som en hvilken som helst anden readymade. Det har desuden den fordel, at det fuldstændigt mangler kommerciel værdi," så kan Duchamp ikke hentyde til andet, end at det, som det egentlig kommer an på, ikke er andet end betragterens katá-logos.

Betydningen for litteraturen, altså den litterære kultur, af en sådan under- eller modtekst kan lige så lidt overvurderes, som den kan overskues. Tendenserne var allerede at se hos Rabelais og Cervantes, og i nyere tid ser vi dem i alt fra Perec og OuLiPo (som i en vis forstand selv forsøgte at skrive 'kolofonisk'), over de litterære genrers forskellige lancerings- og samlerkulturer, til alle nutidens digitale litterære praksiser. Sagen er givetvis, at litteratur, som en kultur, ikke kan undgå at producere sine undertekster.

Perec, ja. Den første bog, jeg købte efter Rosenthals katalog, var en billig pocketbog til 10 euro, netop Georges Perec: Ein Kunstkabinett. Geschichte eines Gemäldes 
(Fischer Taschenbuch Verlag, 1992). Det er en fantastisk god tekst om kunstforfalskning, som oven i købet afsluttes med et dejligt - men åbenlyst fiktivt - katalog af malerier. Det bemærkelsesværdige - for mig - var dog, at ved siden af Rosenthals katalog stod Perecs tekst sig svag og lidt løjerlig. Muligvis illustrerer denne sammenligning, at virkeligheden altid overgår fantasien; i hvert tilfælde illustrerer den det faktum, at teksten ikke kan indeholde sin egen under- eller modtekst. Den kan kun læseren, samleren eller betragteren producere. Men samtidig er jeg ikke i tvivl om, at Perec ville være enig i min dom: kataloget er den post-autoritære litteraturs form, og kartotekskortet er dens objekt. 